\title{
SISTEM INFORMASI KERJA PRAKTEK DAN TUGAS AKHIR PROGRAM STUDI SISTEM KOMPUTER
}

\author{
Karlina Kusumaningrum ${ }^{1)}$, Adian Fatur Rochim ${ }^{2)}$, Rinta Kridalukmana ${ }^{3)}$ \\ Program Studi Sistem Komputer, Fakultas Teknik, Universitas Diponegoro \\ Jl. Prof. Sudharto, Tembalang, Semarang \\ email:karlina_k@rocketmail.com
}

\begin{abstract}
Information technology development today resulted in the growing number of internet users. Easy access of the internet makes it as a media presentation of data to both individuals and institutions. It is similar with Computer System major that has taken advantage of the Internet to provide a variety of information to both academic and community service in the field of information technology. But it is still using manual method to organize and inventory data associated with the On-Job Training (KP) and Final Project (TA) in a site. One way to ease the data organization is to design an information system that can record and organize all the data held by the Computer System.

Design and Implementation phase begins with system requirement analysis. Its objection is to get a proper system specification. In design phase, Data Flow Diagram is used to represent data in a logic way. The result from design phase then implements with PHP programming language, associated with Database Management System MySQL, and Javascript to generate a dynamic web-based information system.

The previous research "Perancangan Sistem Informasi Seminar dan Tugas Akhir Mahasiswa Jurusan Teknik Elektro Undip" was to organize database final project consist of schedule, seminar schedule, and test schedule. It used Unified Modeling Language (UML) consist of use case and activity diagram. The users of this information system were two, that were called admin and student. The result from information testing showed that all features like organizing students data, organizing teacher data, printing KP and TA data, uploading KP and TA data, alerting KP and TA coordinator about the schedule of the students worked well. The current research use Entity Relationship Diagram model system. This information system has five users, that are admin, student, teacher, KP coordinator, and TA coordinator.
\end{abstract}

Keywords : web-based information system, PHP, MySQL, Javascript, KP and TA

\section{PENDAHULUAN}

\subsection{Latar Belakang}

Perkembangan Ilmu Pengetahuan dan Teknologi yang semakin komplek mampu mempengaruhi pola pikir manusia. Kemajuan ini telah mendorong manusia untuk berusaha mengatasi segala permasalahan yang timbul di sekitarnya. Terutama dalam bidang akademik, peranan basis data sangat penting. Pemrosesan basis data menjadi perangkat andalan yang kehadirannya sangat diperlukan oleh berbagai institusi dan perusahaan. Basis data tidak hanya mempercepat dalam memperoleh informasi, tetapi juga dapat meningkatkan pelayanan kepada pelanggan sehingga efektifitas waktu dapat dimaksimalkan.

Teknologi yang digunakan untuk mendata informasi tersebut masih bersifat manual dan sederhana, yaitu menggunakan Microsoft Office Excel. Berkembangnya teknologi dalam bidang informasi saat ini, maka sistem yang lama tersebut semakin tertinggal dan sulit digunakan untuk membagi data tersebut untuk keperluan pihak - pihak lain. Program Studi Sistem Komputer membutuhkan sebuah sistem informasi yang mudah digunakan dan lebih baik untuk menyebarkan data tersebut. Untuk itu dapat digunakan sebuah sistem informasi berbasis web yang dapat menyebarkan data tersebut secara luas dan mudah diakses melalui jaringan internet. Web sistem informasi tersebut nantinya diharapkan dapat menjadi jalan keluar yang baik dalam hal mendata mahasiswa yang sudah melaksanakan kerja pratek dan tugas akhir, serta menampilkan data tersebut jika sewaktu - waktu diperlukan. Sistem informasi ini dibuat menggunakan bahasa pemrograman PHP, sistem basis data MySQL, serta CSS template sebagai frameworknya.

Sistem informasi ini terdapat fitur berupa pesan dan berita. Fitur pesan yang dapat digunakan oleh admin yang hendak melaporkan informasi apapun yang berhubungan dengan kerja praktek ataupun tugas akhir langsung ke akun mahasiswa. Sedangkan fitur berita berfungsi memberikan pengumuman yang terkait kerja prkatek dan tugas akhir. Fitur ini nantinya akan dapat berguna juga untuk pihak mahasiswa yang akan melaksanakan kerja prktek dan tugas akhir.

\subsection{Rumusan Masalah}

Berdasarkan latar belakang masalah tersebut dapat dibuat suatu rumusan masalah, yaitu:

"Bagaimana mengolah data kerja praktek dan tugas akhir milik Teknik Sistem Komputer yang berupa data ke dalam sistem informasi kerja praktek dan tugas akhir berbasis web “.

\subsection{Tujuan}

Tujuan dari tugas akhir ini adalah adalah untuk merancang dan membuat perangkat lunak Sistem Informasi kerja praktek dan tugas akhir yang berbasis web.

\subsection{Batasan Masalah}

Untuk menyederhanakan pembahasan pada Tugas

1) Mahasiswa Sistem Komputer Undip

2) Dosen Sistem Komputer Undip 
Akhir ini, masalah dibatasi sebagai berikut :

1. Program aplikasi yang dibuat merupakan prototipe sistem informasi berbasis web yang ditujukan untuk memasukan dan menampilkan data kerja praktek dan tugas akhir di Program Studi Sistem Komputer.

2. Bahasa pemrograman yang digunakan adalah PHP 5.2.5.

3. Basis data yang digunakan adalah MySQL 5.0.51

4. Web Server yang digunakan adalah Apache 2.2.6

\section{LANDASAN TEORI}

\subsection{Sistem Informasi}

Sistem informasi adalah sekumpulan komponen pembentuk sistem yang mempunyai keterkaitan antara satu komponen dengan komponen lainnya yang bertujuan menghasilkan suatu informasi dalam suatu bidang tertentu. Dalam sistem informasi diperlukannya klasifikasi alur informasi, hal ini disebabkan keanekaragaman kebutuhan akan suatu informasi oleh pengguna informasi. Kriteria dari sistem informasi antara lain, fleksibel, efektif dan efisien.

Sistem informasi berbasis komputer (Computer Based Information System) terdiri dari komponenkomponen seperti:

- Perangkat keras (hardware) yaitu perangkat keras komponen untuk melengkapi kegiatan memasukan data, memproses data dan keluaran data.

- Perangkat lunak (software) yaitu program dan instruksi yang diberikan ke komputer untuk menjalankan sistem.

- Database yaitu kumpulan data dan informasi yang diorganisasikan sedemikian rupa sehingga mudah diakses pengguna sistem informasi.

- Telekomunikasi yaitu komunikasi yang menghubungkan antara pengguna sistem dengan sistem komputer secara bersama-sama ke dalam suatu jaringan kerja yang efektif.

- Manusia yaitu personel dari sistem informasi, meliputi manajer, analis, programmer dan operator serta bertanggung jawab terhadap perawatan sistem.

- Prosedur yaitu tata cara yang meliputi strategi, kebijakan, metode, dan peraturan-peraturan dalam menggunakan sistem informasi.[9].

\subsection{Tugas Akhir}

Tugas Akhir adalah sebuah kurikulum wajib yang ada di program studi sistem computer. Tugas Akhir juga memiliki syarat minimal 100 sks dan tanpa nilai E, sudah lulus kerja praktek dan sudah lulus matakuliah metodologi penelitian. Tugas Akhir bisa dilaksanakan pada saat mahasiswa duduk di bangku semester 8 . Karena Kerja Praktek dan Tugas Akhir penting dan masuk dalam kurikulum wajib, maka diperlukan suatu Sistem Informasi Kerja Praktek dan Tugas Akhir.

Sistem Informasi Kerja Praktek dan Tugas Akhir ini bertujuan antara lain untuk:
- Mempermudah penyampaian informasi kepada koordinator KP dan TA

- Mempermudah mengelola data bagi pihak admin.

- Mempermudah mahasiswa untuk input data.

- Mempermudah dosen pembimbing untuk mengetahui berapa saja jumlah mahasiswa bimbingannya.

\subsection{PHP (PHP Hypertext Preprocessor)}

PHP adalah bahasa pemrograman yang paling banyak dipakai saat ini. PHP banyak dipakai untuk memrogram situs web dinamis, walaupun tidak tertutup kemungkinan digunakan untuk pemakaian lain.[18]

Model kerja PHP hampir sama dengan HTML, hanya saja dalam prosesnya, saat berkas PHP dijalankan, akan melakkan pengolahan data yang nantinya baru ditampilkan dalam bentuk HTML, berbeda dengan HTML yang hanya menampilkan data tanpa pengolahan. Proses kerja tersebut dapat kita lihat pada gambar 1 berikut.[8]

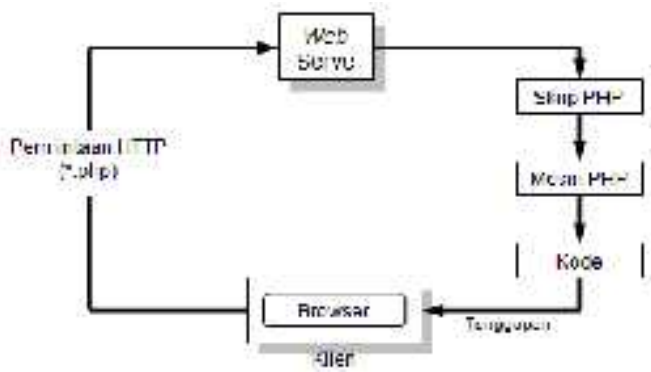

Gambar 1. Diagram proses kerja PHP

\subsection{MySQL}

MySQL adalah Relational Database Management System (RDBMS) yang didistribusikan secara gratis dibawah lisensi GPL (General Public License). Dimana setiap orang bebas untuk menggunakan MySQL, namun tidak boleh dijadikan produk turunan yang bersifat closed source atau komersial.

MySQL sebenarnya merupakan turunan salah satu konsep utama dalam database sejak lama, yaitu SQL (Structured Query Language). SQL adalah sebuah konsep pengoperasian database, terutama untuk pemilihan atau seleksi dan pemasukan data, yang memungkinkan pengoperasian data dikerjakan dengan mudah secara otomatis. [10]

\subsection{Pendekatan Terstruktur}

Dalam perancangan perangkat lunak ini, digunakan salah satu pendekatan yang dikenal dengan istilah pendekatan terstruktur dengan tools yang digunakan adalah Diagram konteks dan DFD, serta untuk perancangan basis data menggunakan pemodelan ERD dan proses normalisasi. [5]

\subsubsection{Diagram Konteks}

Diagram konteks merupakan tingkatan tertinggi dalam diagram aliran data dan hanya memuat satu 
proses, menunjukkan sistem secara keseluruhan. Dapat dikatakan juga bahwa diagram konteks menggambarkan hubungan sistem dengan lingkungan luarnya.[5]

\subsubsection{Data Flow Diagram}

DFD ini merupakan alat perancangan sistem yang berorientasi pada alur data dengan konsep dekomposisi dapat digunakan untuk penggambaran analisa maupun rancangan. Pada dasarnya Data Flow Diagram adalah dekomposisi dari Diagram Konteks. [1]

\subsubsection{Entity Relationship Diagram}

Entity Relational Diagram merupakan salah satu pemodelan data konseptual yang paling sering digunakan dalam proses pengembangan basis data bertipe relasional. Model E-R adalah rincian yang merupakan representasi logika dari data pada suatu organisasi atau area bisnis tertentu. [7]

\section{PERANCANGAN SISTEM}

Perancangan sistem ini meliputi analisis kebutuhan yang kemudian dilanjutkan dengan perancangan proses bisnis dengan menggunakan Context Diagram atau Diagram Konteks, Data Flow Diagram (DFD) dan perancangan basis data dengan menggunakan Entity Relationship Diagram (ERD) dan proses normalisasi basis data.

\subsection{Analisis Kebutuhan}

Analisis data telah dilakukan dengan observasi dari lingkungan dimana sistem akan dibangun. Oleh karena itu penulis menyimpulkan kebutuhan rinci sebagai berikut:

- Kebutuhan Fungsional

$\checkmark$ Fasilitas untuk memasukan data mahasiswa.

$\checkmark$ Fasilitas untuk mengunggah data mahasiswa.

$\checkmark$ Fasilitas untuk mencetak surat - surat KP dan TA

$\checkmark$ Fasilitas untuk menampilkan informasi.

$\checkmark$ Fasilitas untuk memasukan informasi.

- $\quad$ Pembagian pengguna menjadi tiga kelompok sebagai berikut :

$\checkmark$ User Mahasiswa (dengan login)

$\checkmark$ User Dosen (dengan login)

$\checkmark$ User Koordinator KP TA (dengan login)

- Administrator (admin)

$\checkmark$ User Mahasiwa dapat mengakses semua fasilitas yang disediakan.

$\checkmark$ User Mahasiswa dapat memasukan data, melihat data. Mengedit data teteapi tidak dapat menghapus data.

$\checkmark$ Adanya administrator untuk mengelola website.

- Kebutuhan Non-Fungsional

Operasional

Aplikasi mampu diakses oleh berbagai browser yang mendukung javascript.

- Keamanan

Penggunaan username dan password dalam form login untuk membedakan tipe user termasuk hak akses masing-masing

\subsection{Pemodelan Perangkat Lunak}

Berikut adalah pemodelan perangkat lunak yang menggunakan Diagram konteks, Data Flow Diagram, dan Entity Relationship Diagram.

\subsubsection{Diagram Konteks}

Diagram konteks merupakan tingkatan tertinggi dalam diagram aliran data dan hanya memuat satu proses, menunjukkan sistem secara keseluruhan. Semua entitas eksternal yang ditunjukkan pada diagram konteks berikut aliran data-aliran data utama menuju dan dari sistem. Diagram konteks ini tidak memuat penyimpanan data dan tampak sederhana untuk diciptakan, begitu entitas-entitas eksternal serta aliran data-aliran data menuju dan dari sistem.

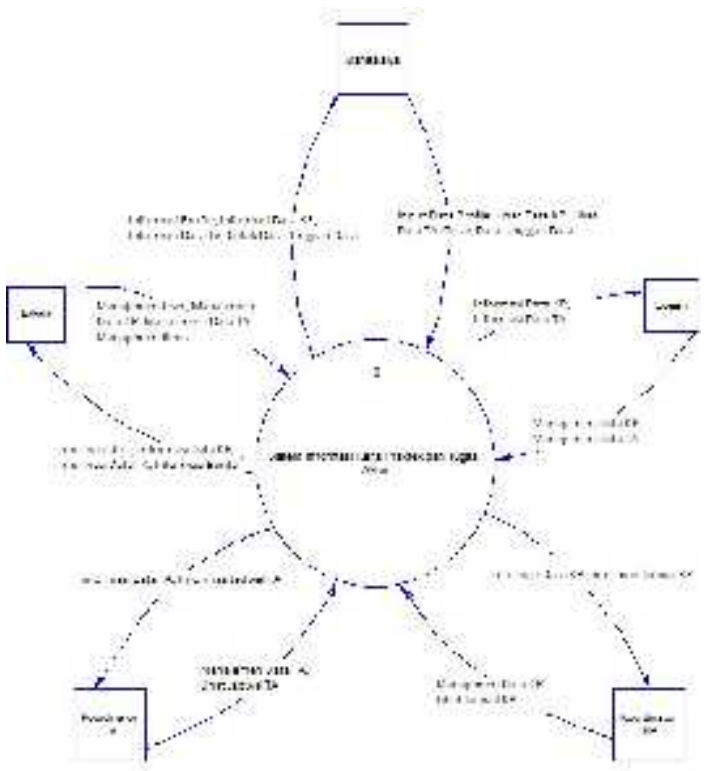

Gambar 2. Diagram konteks

Konteks Diagram diatas dapat dilihat bahwa proses yang terjadi dalam aplikasi Sistem Informasi Kerja Praktek dan Tugas Akhir melibatkan lima sumber atau tujuan data yaitu admin, mahasiswa, dosen, koordinator $\mathrm{kp}$, koordinator ta.

- Admin

Admin dapat melakukan manajemen user, manajemen data KP, manajemen data TA, manajemen berita.

- Dosen

Dosen dari aplikasi ini dapat melakukan manajemen data KP dan manajemen data TA.

- Mahasiswa

Mahasiswa dari apliakasi ini dapat melakukan input data profile, lihat data $\mathrm{kp}$, lihat data ta, cetak data $\mathrm{kp}$, cetak data ta, unggah data $\mathrm{kp}$, unggah data ta.

- Koordinator KP

Koordinator KP dari apliakasi ini dapat melakukan manajemen data $\mathrm{kp}$ dan lihat jadwal 
$\mathrm{kp}$.

- Koordinator TA

Koordinator TA dari apliakasi ini dapat melakukan manajemen data ta dan lihat jadwal ta.

\subsubsection{Data Flow Diagram}

Data flow diagram menggambarkan sistem sebagai jaringan kerja antar fungsi yang berhubungan satu dengan yang lain dengan aliran dan penyimpanan data. Data Flow Diagram Level 1 pada gambar 3 memuat proses-proses inti yang ada didalam sistem, yaitu proses pengolahan user, proses pengolahan data $\mathrm{kp}$, proses pengolahan data ta dan proses manajemen berita.

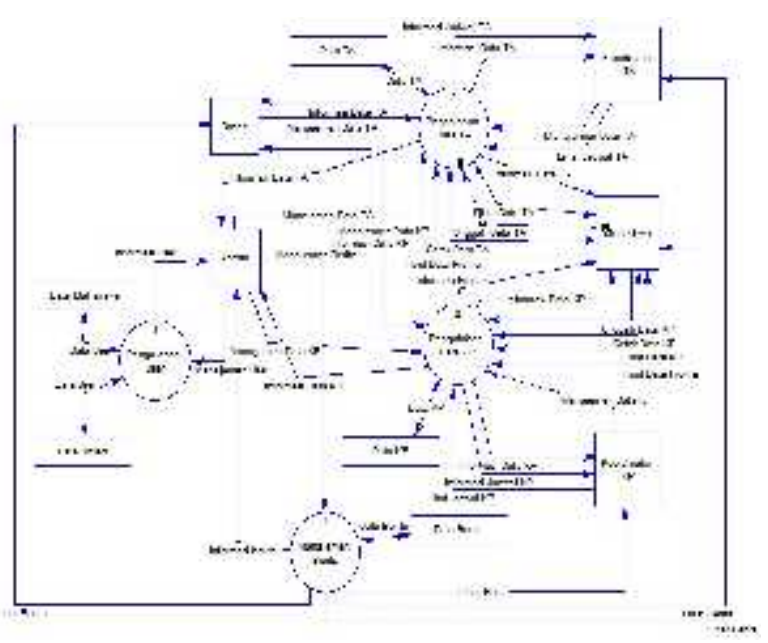

Gambar 3. Data flow diagram level 1

\subsubsection{Perancangan Basis Data Pada Sistem}

Berikut dapat kita lihat E-R Diagram sistem SI KP TA Siskom

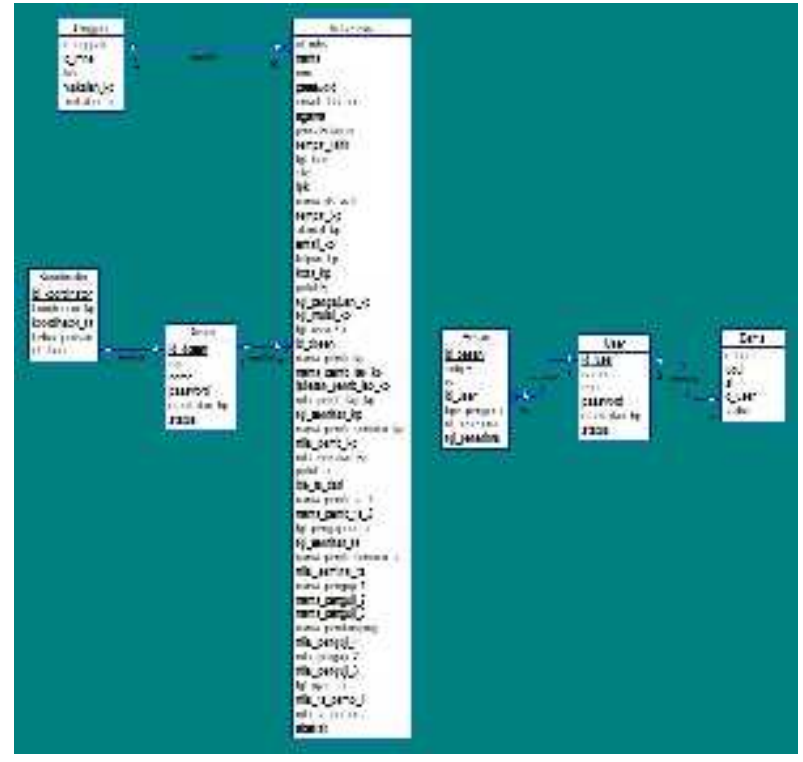

Gambar 4. E-R Diagram

Gambar 4 diatas dapat kita lihat bahwa entitas admin memiliki relasi terhadap entitas pesan. Relasi yang terjadi adalah relasi satu ke banyak tetapi hanya satu arah saja. Dalam relasi ini, admin dapat mengakses entitas pesan. Selain entitas pesan, entitas admin juga memiliki relasi terhadap entitas berita. Entitas berita yang terjadi adalah relasi satu ke satu. Dalam relasi ini, entitas admin dapat mengakses entitas berita.

Entitas mahasiswa memiliki relasi terhadap entitas unggah. Relasi yang terjadi adalah relasi satu ke satu. Dalam relasi ini entitas mahasiswa dapat mengakses relasi entitas unggah

Entitas dosen memiliki relasi terhadap entitas mahasiswa. Relasi yang terjadi adalah relasi satu ke banyak. Dalam relasi ini entitas dosen dapat mengakses entitas mahasiswa. Selain entitas mahasiswa, entitas dosen juga memiliki relasi terhadap entitas koordinator. Entitas koordinator yang terjadi adalah relasi satu ke satu. Dalam relasi ini, dosen dapat mengakses entitas koordinator

\section{PENGUJIAN SISTEM}

Pengujian Sistem Informasi Kerja Praktek dan Tugas Akhir dapat dilihat pada tabel 4.1 Pengujian aplikasi dibawah ini :

Tabel 4.1 Pengujian aplikasi

\begin{tabular}{|c|c|c|c|}
\hline $\begin{array}{c}\text { Nama } \\
\text { Pengujian }\end{array}$ & $\begin{array}{c}\text { Bentuk } \\
\text { Pengujian }\end{array}$ & $\begin{array}{l}\text { Hasil Yang } \\
\text { Diharapkan }\end{array}$ & $\begin{array}{c}\text { Hasil } \\
\text { Pengujian }\end{array}$ \\
\hline $\begin{array}{l}\text { Pengujian } \\
\text { Login }\end{array}$ & $\begin{array}{l}\text { Memasukkan } \\
\text { username } \\
\text { dan } \\
\text { password }\end{array}$ & $\begin{array}{c}\text { Muncul } \\
\text { tampilan } \\
\text { halaman } \\
\text { utama }\end{array}$ & Berhasil \\
\hline $\begin{array}{l}\text { Pengujian } \\
\text { Menu Buat } \\
\text { User Baru }\end{array}$ & $\begin{array}{c}\text { Menambah } \\
\text { user baru }\end{array}$ & $\begin{array}{c}\text { Muncul } \\
\text { tampilan } \\
\text { buat } u s e r \\
\text { baru }\end{array}$ & Berhasil \\
\hline $\begin{array}{l}\text { Pengujian } \\
\text { Menu } \\
\text { Dosen }\end{array}$ & $\begin{array}{l}\text { Mengklik } \\
\text { menu dosen }\end{array}$ & $\begin{array}{c}\text { Muncul } \\
\text { tampilan } \\
\text { menu dosen } \\
\text { beserta } \\
\text { nama, nip } \\
\text { dan email }\end{array}$ & Berhasil \\
\hline $\begin{array}{l}\text { Pengujian } \\
\text { Menu } \\
\text { Mahasiswa }\end{array}$ & $\begin{array}{l}\text { Mengklik } \\
\text { menu } \\
\text { mahasiswa }\end{array}$ & $\begin{array}{c}\text { Muncul } \\
\text { tampilan } \\
\text { menu } \\
\text { mahasiswa } \\
\text { beserta } \\
\text { nama, nim, } \\
\text { ipk, dll. }\end{array}$ & Berhasil \\
\hline $\begin{array}{l}\text { Pengujian } \\
\text { Menu } \\
\text { Jadwal KP }\end{array}$ & $\begin{array}{l}\text { Mengklik } \\
\text { menu jadwal } \\
\text { KP }\end{array}$ & $\begin{array}{c}\text { Muncul } \\
\text { tampilan } \\
\text { jadwal KP } \\
\text { mahasiswa }\end{array}$ & Berhasil \\
\hline $\begin{array}{l}\text { Pengujian } \\
\text { Menu } \\
\text { Jadwal TA }\end{array}$ & $\begin{array}{c}\text { Mengklik } \\
\text { menu jadwal } \\
\text { TA }\end{array}$ & $\begin{array}{c}\text { Muncul } \\
\text { tampilan } \\
\text { jadwal TA } \\
\text { mahasiswa }\end{array}$ & Berhasil \\
\hline $\begin{array}{l}\text { Pengujian } \\
\text { Menu } \\
\text { Berita }\end{array}$ & $\begin{array}{l}\text { Mengklik } \\
\text { menu berita }\end{array}$ & $\begin{array}{c}\text { Muncul } \\
\text { tampilan } \\
\text { menu berita } \\
\text { beserta judul } \\
\text { dan isi }\end{array}$ & Berhasil \\
\hline
\end{tabular}




\begin{tabular}{|c|c|c|c|}
\hline $\begin{array}{c}\text { Pengujian } \\
\text { Menu } \\
\text { Unggah }\end{array}$ & $\begin{array}{c}\text { Mengklik } \\
\text { menu } \\
\text { unggah dan } \\
\text { memilih file } \\
\text { yang akan } \\
\text { diunggah }\end{array}$ & $\begin{array}{c}\text { Muncul } \\
\text { tampilan } \\
\text { menu unggah } \\
\text { data } \\
\text { berformat } \\
\text {.pdf dan .jpeg }\end{array}$ & Berhasil \\
\hline & & $\begin{array}{c}\text { Muncul } \\
\text { menu cetak }\end{array}$ & \\
Pengujian & Mengklik & $\begin{array}{c}\text { data beserta } \\
\text { Menu }\end{array}$ & Berhasil \\
menu Cetak & atang & akan di \\
cetak Data & Data & & \\
& & & \\
\end{tabular}

\section{Pengujian Menu Login}

Menu ini digunakan admin untuk mengetahui level pengguna Sistem Informasi dibagi menjadi lima, yaitu admin, mahasiswa, dosen, koordinator kp, koordinator ta, dengan hak akses yang berbeda.

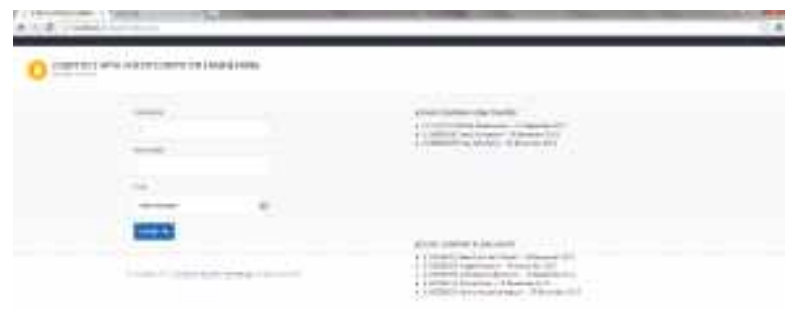

Gambar 5. login form

\section{Pengujian Menu Buat User Baru}

Hak akses untuk Menu Buat User Baru ini adalah user Administrator. Menu Buat User Baru ini berfungsi untuk membuat user baru dengan level admint sebagai administrator

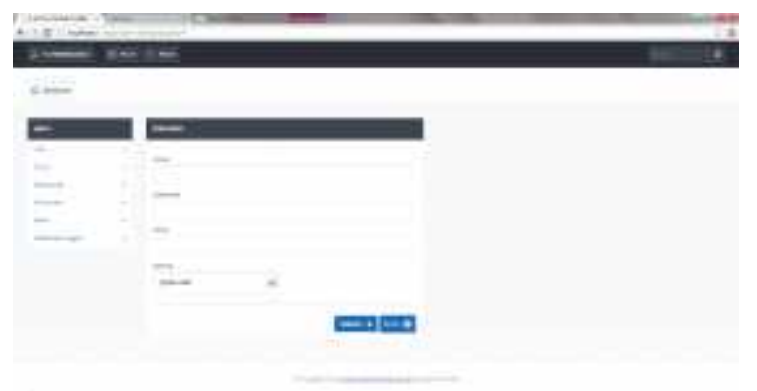

Gambar 6. Menu buat user

\section{Pengujian Menu Dosen}

Administrator memiliki hak untuk mengakses Menu Dosen ini. Menu dosen ini berfungsi untuk memasukkan data dosen ke dalam database.

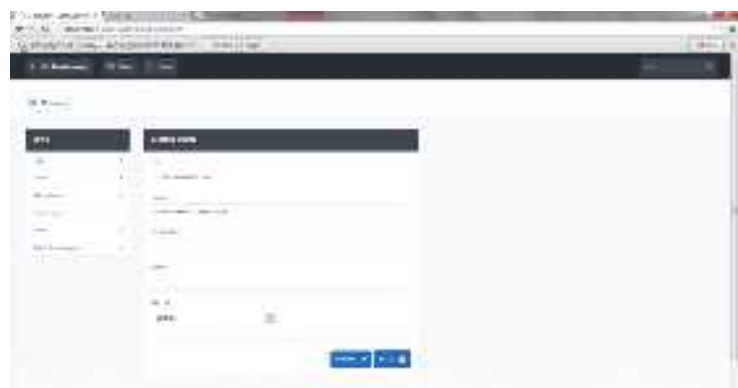

Gambar 7. Menu Dosen

\section{Pengujian Menu Mahasiswa}

Semua user memiliki hak akses untuk membuka menu mahasiswa. menu mahasiswa ini berfungsi untuk memasukan data mengenai mahasiswa.

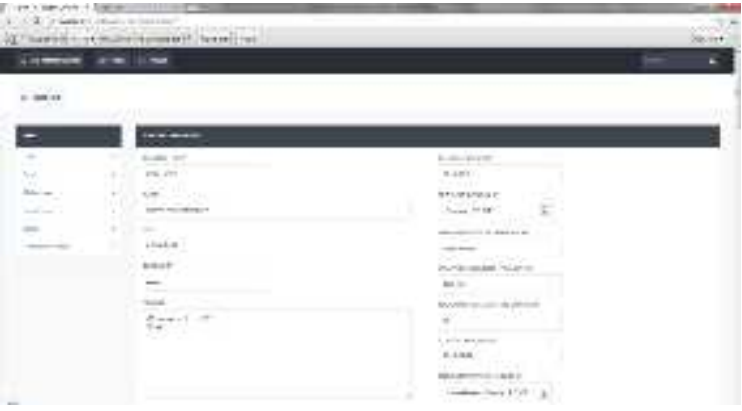

Gambar 8. Menu Mahasiswa

\section{Pengujian Menu Jadwal KP dan TA}

Memiliki hak akses untuk menu jadwal KP dan TA ini adalah Koordinator KP dan TA. Menu ini berfungsi untuk melihat jadwal mahaiswa KP dan mahasiswa TA

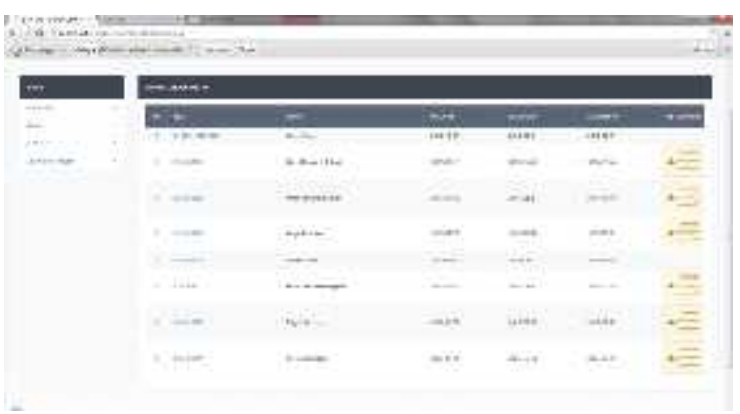

Gambar 9 Menu jadwal KP 


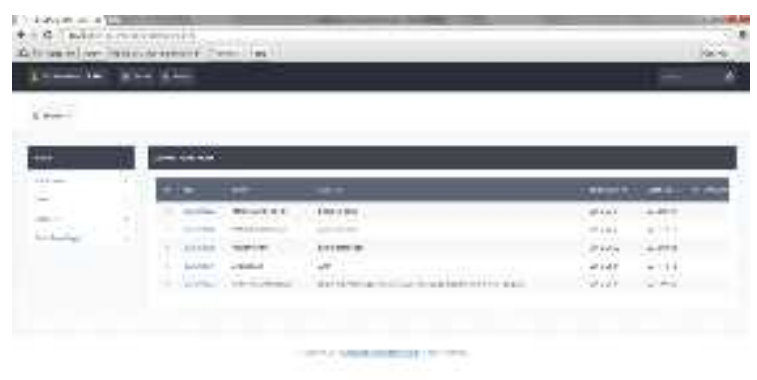

Gambar 10. Menu jadwal TA

\section{Pengujian Menu Berita}

Administrator memiliki hak akses untuk Menu Berita. Menu input berita ini berfungsi untuk memberikan informasi yang berhubungan

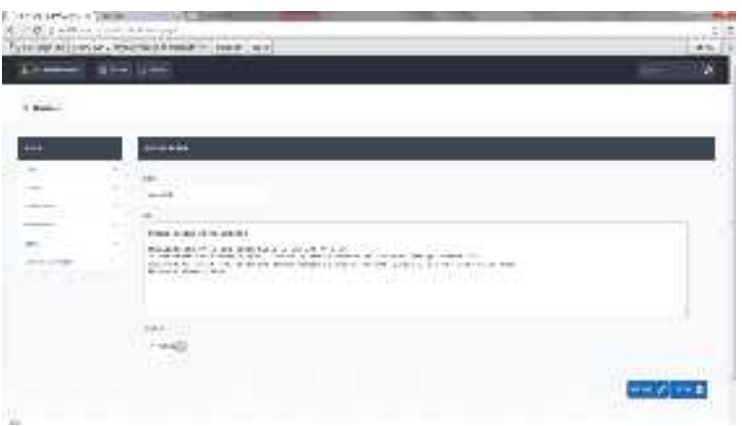

Gambar 11. Menu Berita

\section{Pengujian Menu Unggah Data}

Mahasiswa memiliki hak akses untuk Menu Unggah Data. Menu Unggah Data ini berfungsi untuk mengunggah data mahasiswa berupa foto dan makalah KP dan TA dalam .JPEG dan .PDF.

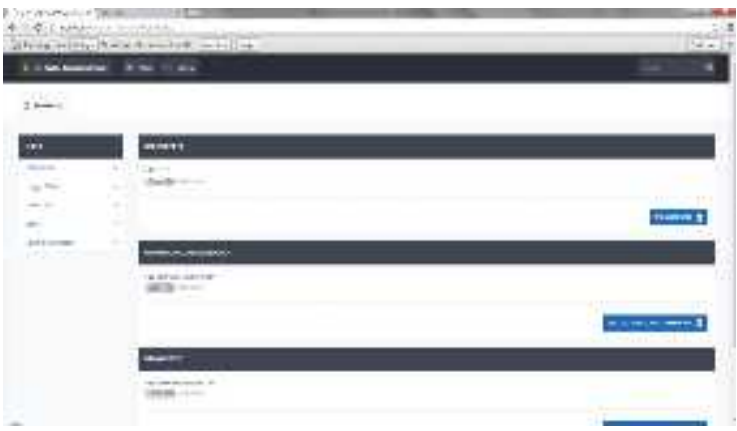

Gambar 12. Menu unggah data

\section{Pengujian Menu Cetak Data}

Memiliki hak akses untuk Menu Cetak Data ini adalah mahasiswa. Menu Cetak Data ini berfungsi untuk mencetak surat - surat yang di butuhkan untuk KP dan TA

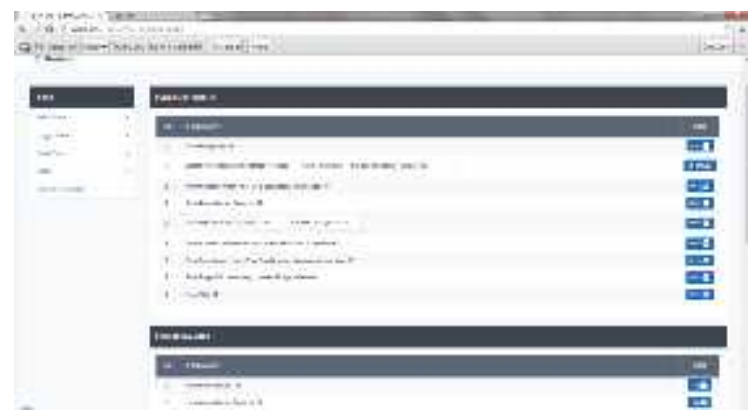

Gambar 13. Menu Cetak Data

\section{PENUTUP}

\subsection{Kesimpulan}

Kesimpulan yang dapat diambil dari hasil pengujian dan pembahasan adalah sebagai berikut.

1. Berdasarkan hasil pengujian, admin dapat melakukan perintah add user, edit user, dan publish berita, tetapi tidak bisa menghapus data mahasiswa

2. Mahasiswa dapat melakukan perintah edit data pribadi, upload data, dam cetak data

3. Dosen dapat melakukan perintah edit data nilai mahasiswa, tetapi tidak bisa mengahapus data mahasiswa

4. Koordinator KP dan koordinator TA dapat melihat jadwal $\mathrm{kp}$ mahasiswa dan menghapus data mahasiswa, tetapi apabila mau dihapus masih bisa di history.

5. Sistem Informasi Kerja Praktek dan Tugas Akhir bermanfaat untuk mengolah data berupa data - data kerja praktek dan tugas akhir milik Teknik Sistem Komputer.

6. Tampilan design Sistem Informasi Kerja Praktek dan Tugas Akhir ini masih sangat sederhana.

\subsection{Saran}

Adapun saran yang dapat diberikan sehubungan dengan pelaksanaan penelitian ini adalah sebagai berikut.

1. Aplikasi Sistem Informasi Kerja Praktek dan Tugas Akhir ini dapat dikembangkan lebih lanjut dengan menggabungkannya dengan layanan berbasis perangkat bergerak (mobile) yang dapat diakses melalui Handphone, PDA dan Smartphone.

2. Dapat dikembangkan aplikasi Sistem Informasi Bantuan Pengembangan dan Peningkatan Pendidikan dengan menggunakan bahasa pemrograman selain PHP dan mesin basis data selain MySQL agar dapat dibandingkan kinerjanya. 


\section{DAFTAR PUSTAKA}

[1] Whitekom, Mark dan Mark, Bill, Seluk Beluk Database Relasional, Erlangga, Jakarta, 2003.

[2] Madcoms. Aplikasi Program PHP dan MySql, Penerbit Andi, Yogyakarta, 2004.

[3] M, David, Dasar-Dasar Desain Dan Implementasi Database Processing, Erlangga, Jakarta, 2005.

[4] Ladjamudin, Al Bahra Bin, Analisis dan Desain Sistem Informasi, Penerbit Graha Ilmu, Yogyakarta, 2007.

[5] Mata, A.Ramon, dkk, Dasar-Dasar Database Relasional, Schaum's Otline Erlangga, Jakarta, 2007.

[6] Hakim, Lukmanul, Membokar trik Rahasia Para Master PHP, Loko media, Yogyakarta, 2008.

[7] Kadir, Abdul, Dasar Perancangan dan Implementasi Database Relasional, Andi Ofset, Yogyakarta, 2008.

[8] Kadir, Abdul. Dasar Pemrograman Web Dinamis Menggunakan PHP. Penerbit Andi, Yogyakarta, 2008.

[9] Kristanto, Andri, Perancangan Sistem Informasi dan Aplikasinya, Gaya Media, Yogyakarta, 2008.

[10] Nugroho, Bunafit. Latihan Membuat Aplikasi Web PHP dan MySQL dengan Dreamweaver, Gaya Media, Yogyakarta, 2008.

[11] Hakim, Lukmanul, Jalan pintas menjadi master PHP, Loko media, Yogyakarta, 2009.

[12] Hermawan, C.Widya, ShortCourse : $P H P$ Programming, Wahana Komputer, Semarang, 2009.

[13] Kadir, Abdul, Form Zero tO A Pro Membuat aplikasi Web dengan PHP dan Database MySQL, Penerbit Andi, Yogyakarta, 2009.

[14] Kadir, Abdul, Mastering AJAX dan PHP, Andi Offset, Yogyakarta, 2009.

[15] Kadir, Abdul, Mudah Mempelajari Database MySQL, Penerbit Andi, Yogyakarta, 2009.

[16] Oktavian , Diar Puji, Menjadi Programmer Jempolan Menggunakan PHP. MediaKom, Jakarta, 2010.

[17] Hirin A.M dan Virgi, Cepat Mahir Pemrograman Web demgan PHP dan MySQL Prestasi Pustakaraya, Jakarta, 2011.

[18] ---, http://www.php.net, Agustus 2011.

[19] Adi, A.P dan Sanjaya R, Web Makin Dahsyat dengan JQuery. Kompas Gramedia, Semarang, 2012.

[20] Prasetyo, Hanung, H., Perancangan Sistem Informasi Site Audit Survey PT. Indosat Yang Berbasis Web, Skripsi S-1, Universitas Diponegoro, Semarang, 2012.

\section{BIODATA PENULIS}

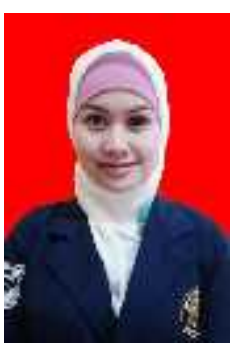

Karlina Kusumaningrum

Lahir di Semarang 27 Mei 1990. Menjalani pendidikannya di Sekolah Dasar Negeri Pati Lor 2, Sekolah Menengah Pertama Negeri 3 Pati, Sekolah Menengah Atas Negeri 1 Pati. Sekarang tengah menyelesaikan pendidikan Strata Satu di Jurursan Teknik Sistem Komputer, Universitas Diponegoro, Semarang angkatan 2008. 